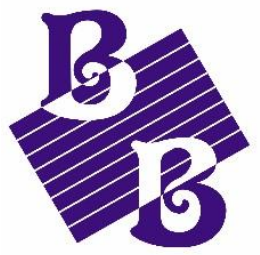

BioBacta



Journal of Bioscience and Applied Research www.jbaar.org

\title{
Knowledge of Adolescents Regarding the Factors Contributing to Mental Health at a Selected Nursing College in Indore
}

\author{
Jinu K Rajan \\ Department of Nursing, College of Applied Medical Sciences \\ Majmaah University, Kingdom of Saudi Arabia \\ Email:jinukrajan@rediffmail.com
}

ABSTRACT

DOI: 10.21608/jbaar.2018.155680

Background: Mental health is simultaneous success at working, loving, creating with the capacity for nature and flexible resolution of conflicts between instincts, conscience, and reality (American Psychiatric Association, 2001).Materials and Methods. The main objectives of the study were to assess the knowledge of adolescents regarding the factors contributing to mental health in a selected college and to compare the knowledge of adolescents on factors contributing to mental health with their selected demographic data. A cross-sectional descriptive study was conducted on 100 college students between 17 to 21 years of age group, selected by stratified random sampling to assess their knowledge regarding factors contributing to mental health by using a close-ended questionnaire at Index Nursing College, Indore. Results: Observation shows that the highest percentage (32\%) of the college students were in the age group of 21 years and above of, a majority (60\%) of them were female students, almost all (90\%) of them were from a nuclear family, the highest percentage (42\%) of them were belongs to income group of Rs. 1251 and above, the highest percentage (53\%) of them were from an urban area, a majority (63\%) of them were Hindus, and a majority (64\%) of them received information from mass media. The total mean knowledge score of college students was $12.37 \pm 4.53$ which is $56.23 \%$ of a maximum obtainable score which revealing average knowledge, whereas the highest mean score $(1.42 \pm 0.62)$ is $71 \%$ of the maximum score on verbatim for relaxation revealing good knowledge \& lowest mean score $(3.63 \pm 1.91)$ which is $51.86 \%$ of the maximum score on nutrition for mental health revealed average knowledge. Association of demographic variables with the knowledge score shows that significant association was found between knowledge scores \& age and class in which studying, whereas no significant association was found between knowledge score and sex, type of family, per month per capita income, residence, religion and source of information. Conclusion: From the findings of the present study it can be concluded that the knowledge of students regarding factors contributing mental was good on regarding relaxation. Overall mean, SD and mean score revealed that students having average knowledge regarding factors contributing to mental health. The knowledge scores of the students when compared with selected demographic variables revealed a significant association was found on age and class in which studying.

Keywords: Knowledge, Adolescents, Mental Health, Adolescent, Factors contributing to mental health 


\section{INTRODUCTION}

The World Health Organization (WHO) defines adolescents as individuals, that are in their second decade of life and face internal conflicts or situations that can compromise directly their mental health(WHO 2012). Adolescence is a time which shows great change and it starts at the age of 1112 years and ends between 18-21 and shows individualities and thinks of future. The ego at this stage can select and integrate talents, aptitude, and skills. On the other hand, the adolescent during the stage of identity formation is to suffer more deeply than ever before or even again from confusion of roles. This stage can cause one to feel isolated, empty, anxious, and indecisive (Hall, C.S.2002 and Morrison, M. 1998). There are different definitions of mental health, it is assumed that the concept is wider than the absence of mental disorders. It is the ability to manage its own life and emotions within a wide range of variations without losing the value of what is real and precious (WHO 2002,2012).

Therefore, adolescent's mental health issues represent important public health challenges worldwide, so preventive measures can help to avoid the development and the risk factors progression faced by adolescents. (Fundo das. 2011).

According to WHO report 2018, Worldwide, it is estimated that $10-20 \%$ of adolescents experience mental health conditions, yet these remain underdiagnosed and undertreated. Signs of poor mental health can be overlooked for many reasons, such as a lack of knowledge or awareness about mental health among health workers, or stigma preventing them from seeking help(WHO 2018).

The risk factors for mental health are widely known and include physical abuse and sexual during childhood; school, family, and community violence: poverty, social exclusion, and educational disadvantage. Psychiatry disorders, parent's drug abuse, and conjugal violence also increase the risks for adolescents as the exposition to social alterations and psychological distress that accompany armed conflicts, natural disasters, and other humanitarian crises. The stigma driven to the adolescent with mental disorders and the human rights violations that are subjected to amplifies the adverse consequences (Brasil Ministério 2010, UNICEF; 2011and Benetti SPC 2007).

The nursing role in mental health is extremely important. The nurse becomes the change agent when he/she breaks with the historical medical model practice that disciplines the subject and communities and does not listen or give value to the subject-citizen in its psychosocial needs(Oliveira AGB, 2003 )

The most common mental illnesses in adolescents are anxiety, attention, mood, and behavior disorders(American Psychiatric Association 2013).

The two approaches are additional and generate important knowledge for the clinical practice. Both designs require research experience, methodological robustness in the research development besides the knowledge for the scientific development( Mynayo MCS, 1993).

This study aims to contribute to the planning and implementation of Knowledge of Adolescents Regarding the Factors Contributing to Mental Health at a Selected Nursing College in Indore.

\section{MATERIALS AND METHODS}

A descriptive design with a cross-sectional survey approach was selected as a research design and approach for the study. The Setting of the Study was in Index Nursing College, Indore. The population for the study was all the students who are in between the age group of 17 to 21 years of Nursing College. The samples for the study were the students, A total of hundred students who were between the age group of 17 to 21 years, studying in Index Nursing College in Indore, where the sample for the study. A stratified random sampling technique which is probability sampling was used to select the sample for the study. 


\section{RESULTS}

The data are organized and presented in the following four sections.

\section{Section-I}

Percentage-wise distribution of college students according to their demographic variables.

Distribution of college students according to their age group shows that highest percentage (32\%) of them were in the age group of 21 years \& above and lowest percentage (11\%) were in the age group of 17 years, More or less similar percentage $(14 \% \& 17 \%)$ of the students were in the age group of 18 years \& 19 years respectively. whereas $26 \%$ of them were in the age group of 20 years. It is observed that as the age in years increases the percentage of students increases.

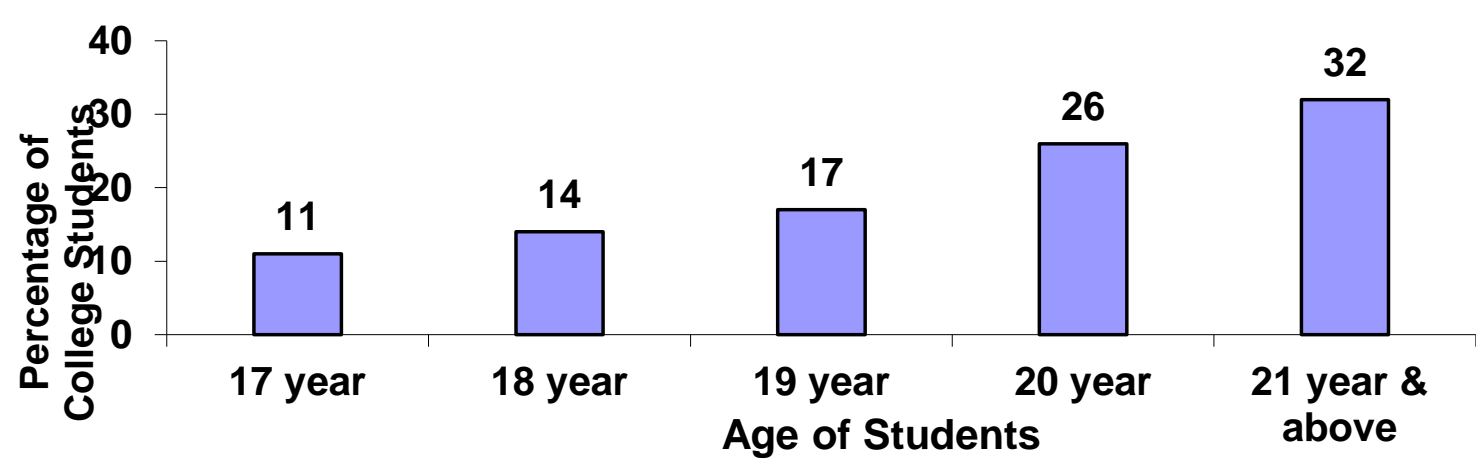

Fig. 3.1 Bar diagram showing the distribution of college students according to their age group. 


\section{Section-II}

Area wise analyses on knowledge of college students regarding factors contributing to mental health

Table 3.1: Factor wise mean, SD, and mean percentage of knowledge score of college students regarding mental health

\begin{tabular}{|l|l|l|l|l|l|}
\hline \multirow{2}{*}{$\begin{array}{l}\text { S. } \\
\text { N. }\end{array}$} & Factors & Max. & \multicolumn{3}{l|}{ Knowledge } \\
\cline { 4 - 6 } & & Score & Mean & SD & \multicolumn{2}{l|}{$\begin{array}{l}\text { Mean } \\
\%\end{array}$} \\
\hline 1. & Knowledge of mental health and its \\
development. & 4 & 2.28 & 1.24 & 57.00 \\
\hline 2. & Nutrition for mental health. & 7 & 3.63 & 1.91 & 51.86 \\
\hline 3. & Stress management skills. & 3 & 1.67 & 0.91 & 55.66 \\
\hline 4. & Understanding limitations & 3 & 1.66 & 0.93 & 55.33 \\
\hline 5. & Relaxation. & 2 & 1.42 & 0.62 & 71.00 \\
\hline 6. & Participation in social activities. & 3 & 1.71 & 0.97 & 57.00 \\
\hline & Total & & 12.37 & 4.53 & 56.23 \\
\hline
\end{tabular}

Factor-wise means, SD, and mean percentage of knowledge scores of college students regarding mental health shows that the overall mean score regarding factors contributing to mental health was $12.37 \pm 4.53$ which is $56.23 \%$ of the maximum score. Among each area of knowledge item, the highest mean score $(1.42 \pm 0.62)$ which is $71 \%$ of the maximum score was obtained in the area of relaxation $\&$ the lowest mean score $3.63 \pm 1.91$ which is $51.86 \%$ of the maximum score was obtained for nutrition for mental health. The mean score for the meaning of mental health \& its development was $2.28 \pm 1.24$ which is $57 \%$ of the maximum score, for stress management was $1.67 \pm 0.91$ which is $55.66 \%$ of the maximum score, for understanding limitation was $1.66 \pm 0.93$ which is $55.33 \%$ of the maximum score and for social activities $1.71 \pm 0.97$ which is $57 \%$ of the maximum score. 


\section{Section-III}

Item wise analysis on the correct response of college student's knowledge regarding factors contributing to mental health

Table 3.2: Item wise analysis of the correct response of college students regarding knowledge of mental health \& its development

\begin{tabular}{|l|l|l|l|}
\hline \multirow{2}{*}{ S.N. } & \multirow{2}{*}{ Item } & \multicolumn{2}{|l|}{ Correct response } \\
\cline { 3 - 4 } & & $\begin{array}{l}\text { No. of correct } \\
\text { responses }\end{array}$ & $\%$ \\
\hline 1 & Mental health is the state of Emotional stability & 55 & 55 \\
\hline 2 & $\begin{array}{l}\text { An individual needs a Healthy environment For } \\
\text { mental health }\end{array}$ & 60 & 60 \\
\hline 3 & $\begin{array}{l}\text { Adolescence is a transitional age that needs to } \\
\text { accept the change }\end{array}$ & 54 & 54 \\
\hline 4 & $\begin{array}{l}\text { Adolescents mental health depends on their } \\
\text { psychosocial development }\end{array}$ & 59 & 59 \\
\hline
\end{tabular}

Item wise analysis of correct responses regarding knowledge of mental health \& its development the majority $(60 \%)$ of college students correctly responded for the item "an individual needs healthy environment for mental health", $59 \%$ of college students correctly responded for the item "mental health of an adolescent is depends on their psychosocial development". 55\% of college students responded correctly to the item "mental health is the state of emotional stability". whereas $54 \%$ of college students responded correctly for the item "adolescence is a transitional age which needs to accept the change". It seems students knew all items related to the meaning and development of mental health. 
Table 3.3: Item wise analysis of the correct response of college students regarding nutrition for mental health

\begin{tabular}{|l|l|l|l|}
\hline \multirow{2}{*}{ S.N } & \multirow{2}{*}{ Item } & \multicolumn{2}{|l|}{ Correct response } \\
\cline { 3 - 4 } & & $\begin{array}{l}\text { No. of correct } \\
\text { responses }\end{array}$ & $\%$ \\
\hline 1. & Vitamin which enhances memory is Vitamin B & 44 & 44 \\
\hline 2. & $\begin{array}{l}\text { Biotin prevents depression and promotes mental } \\
\text { health. }\end{array}$ & 48 & 48 \\
\hline 3. & $\begin{array}{l}\text { Calcium stabilizes neurons and promotes mental } \\
\text { health. }\end{array}$ & 58 & 58 \\
\hline 4. & $\begin{array}{l}\text { Skipping food and taking fast food using beauty } \\
\text { consciousness and adaptation of western culture lead } \\
\text { to an effect on mental health }\end{array}$ & 53 & 53 \\
\hline 5. & Conscious about adequate diet for better mental health & 52 & 64 \\
\hline 6. & $\begin{array}{l}\text { A balanced diet is required for the normal functioning } \\
\text { of brain cells }\end{array}$ & 64 & 44 \\
\hline 7. & $\begin{array}{l}\text { Essential nutrients inadequate amount for proper } \\
\text { development of the brain }\end{array}$ & 44 & 52 \\
\hline
\end{tabular}

Item wise analysis of the correct response of college students regarding nutrition for mental health shows that the majority (64\%) of college students responded correctly for the item "Balanced diet is required for normal functioning of brain cells" and the lowest percentage $(44 \%)$ of college students responded correctly for the items "Vitamin which enhances memory is Vitamin $\mathrm{B}_{6}$ " and "Essential nutrients inadequate amount for proper development of brain" whereas between $50-60 \%$ of students responded correctly for the items "Calcium stabilize neuron and promotes mental health" (58\%), "the vitamin which prevents depression for adolescents and promotes mental health is Biotin" (48\%), "skipping food and taking fast food using beauty conscious and adaptation of western culture lead to an effect on mental health" (53\%) and "conscious about adequate diet for better mental health" $(52 \%)$. It seems that students knew about items related to nutrition for mental health.

Table 3.4: Item wise analysis of the correct response of college students regarding relaxation

\begin{tabular}{|l|l|l|l|}
\hline \multirow{2}{*}{ S. N. } & \multirow{2}{*}{ Item } & \multicolumn{3}{|l|}{ Correct response } \\
\cline { 3 - 4 } & & $\begin{array}{l}\text { No. of correct } \\
\text { responses }\end{array}$ & $\%$ \\
\hline 1. & $\begin{array}{l}\text { Ventilating feelings helps to avoid an accumulation } \\
\text { of stress }\end{array}$ & 73 & 73 \\
\hline 2. & When tense Share feelings with friends & 69 & 69 \\
\hline
\end{tabular}

Item wise analysis of the correct response of college students regarding relaxation shows that most (73\%) of the college students correctly responded for the item "Ventilating feelings helps to avoid an accumulation of stress" Whereas $69 \%$ of students correctly responded for the item "When tense Share feelings with friends". It seems that students knew regarding relaxation. 
Table 3.5: Item wise analysis of the correct response of college students regarding Participation in social activities

\begin{tabular}{|l|l|l|l|}
\hline \multirow{2}{*}{ S. N. } & \multirow{2}{*}{ Item } & \multicolumn{2}{|l|}{ Correct response } \\
\cline { 3 - 4 } 1. & $\begin{array}{l}\text { Sports are essential because it helps to be } \\
\text { mentally healthy }\end{array}$ & 57 & 57 \\
\hline responses
\end{tabular}

Item wise analysis of the correct response of college students regarding "contribution of participation in social activities in mental health" shows that majority $(65 \%)$ of college students correctly responded for the item "While in a group, an individual can participate in Recreational activities" and lowest percentage
(49\%) of students responded correctly for the item "group activities help in being mentally healthy" Whereas $57 \%$ of students correctly responded for the items "sports are essential because it helps to be mentally healthy". It seems students knew for all item related to participation in group activities

\section{Section-IV}

\section{Level of knowledge of college students regarding factors contributing to mental health}

Table 3.6: Level of knowledge of college students regarding factors contributing to mental health.

\begin{tabular}{|l|l|l|l|}
\hline S. N. & Level of knowledge & No. & Percentage \\
\hline 1. & Very poor (0-20) & 7 & 7 \\
\hline 2. & Poor (21-40) & 14 & 14 \\
\hline 3. & Average (41-60) & 34 & 34 \\
\hline 4. & Good (61-80) & 41 & 41 \\
\hline 5. & Excellent (81-100) & 4 & 4 \\
\hline & Total & 100 & 100 \\
\hline
\end{tabular}

Percentage-wise distribution of knowledge score shows that 41 college students $(41 \%)$ scored between 60-80 which shows good knowledge towards factors contributing to mental health. Only 4 students (4\%) score 80-100 having excellent knowledge. Most of the remaining students (34) which means $34 \%$ scored between 40-60 having average knowledge. Only 14 students $(14 \%)$ students scored between 24-40 that shows poor knowledge and 7 students (7\%) students scored 0-20 having very poor knowledge regarding factors contributing to mental health. Here, It can be interpreted that the highest percentage $(41 \%)$ of the college students had good knowledge regarding factors contributing to mental health. 


\section{Section-V}

Comparison of knowledge of college students regarding factors contributing to mental health with their demographic variables.

Table 3.7: Comparison of mean, SD and mean percentage of knowledge score of college students regarding factors contributing to mental health concerning age.

\begin{tabular}{|l|l|l|l|l|l|}
\hline S.N. & Age in years & $\begin{array}{l}\text { No. } \\
\text { respondents }\end{array}$ & Mean & SD & Mean\% \\
\hline 1. & 17. & 11 & 8.27 & 4.58 & 37.59 \\
\hline 2. & 18 & 14 & 12.64 & 4.25 & 57.45 \\
\hline 3. & 19 & 17 & 11.65 & 4.62 & 52.95 \\
\hline 4. & 20 & 26 & 12.62 & 3.83 & 57.36 \\
\hline 5. & $21 \&$ above & 32 & 13.84 & 4.46 & 62.91 \\
\hline Total & & 100 & 12.37 & 4.53 & 56.23 \\
\hline
\end{tabular}

Age-wise distribution of the mean, SD and mean percentage of knowledge score of college students shows that the highest mean score $(13.84 \pm 4.46)$ which is $62.91 \%$ of the total score was obtained by the college students in the age group of 21 years $\&$ above and the lowest mean score $(8.27 \pm 4.58)$ which is $37.59 \%$ of the total score was for the students in an age of 17 years. The mean score $12.64 \pm 4.25$ which is
$57.45 \%$ of the total score was for the students in the age of 18 years, mean score $11.65 \pm 4.62$ which was $52.95 \%$ of the total score obtained by the students in the age group of 19 years. The mean score $12.62 \pm$ 3.83 which was $57.36 \%$ of the total score for the students in the age group of 20 years. Hence it can be interpreted that as age increases knowledge also increases.

Table 3.8: Comparison of mean, SD and mean percentage of knowledge score of college students regarding factors contributing to mental health concerning the class.

\begin{tabular}{|l|l|l|l|l|l|}
\hline S.N. & Class & $\begin{array}{l}\text { No. } \\
\text { respondents }\end{array}$ & Mean & SD & Mean\% \\
\hline 1. & I year & 25 & 10.12 & 4.28 & 46.00 \\
\hline 2. & II year & 25 & 12.64 & 4.43 & 57.45 \\
\hline 3. & III year & 25 & 12.56 & 4.60 & 57.09 \\
\hline 4. & IV year & 25 & 14.16 & 4.12 & 64.36 \\
\hline Total & & 100 & 12.37 & 4.53 & 56.23 \\
\hline
\end{tabular}


Class wise distribution of the mean, SD and mean percentage of knowledge score of college students shows that the highest mean score $(14.16 \pm 4.12)$ which is $64.36 \%$ of the total score was obtained by the college students in the IV year and the lowest mean score $(10.12 \pm 4.28)$ which is $46 \%$ of the total score was for the students of I year. The mean score $12.64 \pm$
4.43 which is $57.45 \%$ of the total score was for the student's II year and an almost similar mean score (12. $56 \pm 4.60$ ) which was $57.09 \%$ of the total score obtained by the students in III years.

Hence it can be interpreted that students studying in IV years having more knowledge.

Table 3.9: Comparison of mean, SD and mean percentage of knowledge score of college students regarding factors contributing to mental health concerning religion.

\begin{tabular}{|l|l|l|l|l|l|}
\hline S.N. & Religion & $\begin{array}{l}\text { No. of } \\
\text { respondents }\end{array}$ & Mean & SD & Mean\% \\
\hline 1. & Hindu & 63 & 12.59 & 4.63 & 57.23 \\
\hline 2. & Muslim & 11 & 11.45 & 5.00 & 52.04 \\
\hline 3. & Christian & 26 & 12.23 & 4.22 & 55.59 \\
\hline Total & & 100 & 12.37 & 4.53 & 56.23 \\
\hline
\end{tabular}

Religion wise distribution of the mean, SD and mean percentage of knowledge score of college students shows that the highest mean score (12.59 \pm 4.63$)$ which is $57.23 \%$ of the total score was obtained by the college students who were Hindu and almost similar mean score $(12.23 \pm 4.22)$ which was $55.59 \%$ of total score obtained by the students were Christian. The lowest mean score $(11.45 \pm 5.00)$ which is $52.04 \%$ of the total score was for the students who were Muslim. Hence it can be interpreted that students of all religion having average knowledge

\section{Section-VI}

\section{Association between knowledge score and demographic variables of the college students}

Table 3.10. : Association between knowledge score and demographic variables of the college students.

\begin{tabular}{|l|l|l|l|l|}
\hline S.N. & variables & df & $\chi^{2}$ values & Level of significance \\
\hline 1. & Age & 1 & 6.64 & Significant \\
\hline 2. & Sex & 1 & 0.09 & Not significant \\
\hline 3. & Class & 1 & 4.88 & Significant \\
\hline 4. & Type of family & 1 & 0.54 & Not significant \\
\hline 5. & Family income & 1 & 2.09 & Not significant \\
\hline 6. & Residence & 1 & 0.31 & Not significant \\
\hline 7. & Religion & 1 & 0.39 & Not significant \\
\hline 8. & $\begin{array}{l}\text { Source } \\
\text { information }\end{array}$ & 1 & 3.32 & Not significant \\
\hline
\end{tabular}


Association between knowledge score and demographic variable of college students revealed that there is a significant association between knowledge score when compared to their age and class. Hence it can be interpreted that the difference in mean score related to these demographic variables was a true difference not by chance.

\section{DISCUSSION}

\section{Demographic characteristics of the sample}

The highest (32\%) of the college students were in the age group of 21 years \& above whereas lowest percentages $(11 \%)$ were in the age group of 17 years. It may be due to the minimum age of admission in professional courses is 17 years.

A majority (60\%) of the college students were female when compared to male (40\%). Singh M. (2004) also found parallel the findings of the present study reported that female students are more in educational institutions compared to male.

Almost all (90\%) of college students according to their type of family were from nuclear family and $10 \%$ were from joint families. It is concurrent to the findings by Lachowski S. et. al., (2007), who reported that the traditional joint family has been breaking down because of the process of modernization.

The highest percentages (53\%) of college students were from an urban area and $47 \%$ were from a rural area. It is supported by the report of the ministry of environment \& Earsl F. (2001) that the process of urbanization in India since the beginning of the last century reveals a steady increase in the size of its urban population.

\section{Assessment knowledge of college students regarding factors contributing to mental health.}

Area-wise comparison of mean, SD and mean percentage of knowledge scores of college students regarding factors contributing to mental health.

Overall mean knowledge score reveals that the mean score was $12.37 \pm 4.53$ which is $56.23 \%$ of the maximum score revealing average knowledge. However, area wise comparison of mean knowledge score shows that out of six areas related to knowledge on factors contributing to mental health, the highest mean score $(1.42 \pm 0.62)$ which is $71 \%$ of the maximum score on importance of relaxation revealing good knowledge \& minimum mean score $(3.63 \pm 1.91)$ which is $51.86 \%$ of maximum obtainable score obtained for nutrition for mental health which reveals average knowledge. It is contradictory with the study conducted by Cook L. J. (2007) reported that adolescents have less knowledge about mental health.

\section{Nutrition for mental health}

Item wise knowledge of college students regarding nutrition for mental health shows that majority (64\%) of college students knew about the item "a balanced diet is required for normal functioning of brain cells" whereas in other items students having average knowledge such "vitamin which enhances memory is vitamin $\mathrm{B}_{6}$ " (44\%), "biotin prevents depression and promoted mental health" (48\%), "calcium stabilizes neuron and promotes mental health" (58\%), "skipping food and taking fast food using beauty conscious and adaptation of western culture lead to an effect on mental health" (53\%), "conscious about adequate diet for better mental health" (52\%) and "essential nutrients in adequate amount for proper development of brain" (44\%).

\section{Stress management skills}

Item wise knowledge of college students regarding stress management skill shows that the majority (62\%) of college students knew about the item "a mentally healthy person decides according to a situation during problem" and had knowledge about the items "mental relaxation is obtained through adequate sleep" (56\%), and "the meditation reduce stress" (49\%). It is contradictory to the study by Garfinkel B. (2000) reported that adolescents must learn \& practice a coping skill, which they lack, to get them through an immediate problem.

\section{Verbatism for relaxation}


Item-wise knowledge of college students regarding relaxation shows that college students knew about the item "ventilating feelings helps to avoids accumulation of stress" $(73 \%)$ and "when tense share feelings with friends" (69\%).

\section{Participation in social activities}

Item wise knowledge of college students regarding participation in social activities shows that college students knew about the item "while in a group, an individual can participate in recreational activities" $(65 \%)$ and average knowledge about items "sports are essential because it helps to be mentally healthy" (57\%), and "group activities help in being mentally healthy" (49\%).

\section{Comparison of the knowledge scores of college students with demographic variables}

Comparison between the mean, SD and mean percentage of scores with the age group of college students shows that the students in the age group of 21 years and above had the highest mean score (13.84 \pm 4.46) which is $62.91 \%$ of the total score that revealed good knowledge and lowest mean score $(8.27 \pm 4.58)$ which is $37.59 \%$ of the total score was obtained by the student's age group of 17 years.

\section{Conclusion}

From the findings of the present study, it can be concluded that most of the college students were 21 years $\&$ above of age, majority of them were female, most of them were from a nuclear family, most of them were belonging from high socio-economic status when assessed based on monthly income, most of the students were Hindus. Most of the students received information from mass media. The knowledge of students regarding factors contributing to mental was good for relaxation. Overall mean, SD and mean score revealed that students having average knowledge regarding factors contributing to mental health.
The knowledge scores of the students when compared with selected demographic variables revealed a significant association was found on age and class in which studying.

\section{REFERENCES}

- American Psychiatric Association. Diagnostic and statistical manual of mental disorders. 5th ed. Arlington (VA): APA; 2013.

-Benetti SPC, Ramires VRR, Schneider AC, Rodrigues APG, Tremarin D. Adolescência e saúde mental: revisão de artigos brasileiros publicados em periódicos nacionais. Cad Saúde Pública. 2007;23(6):1273-82 .

-Brasil Ministério da Justiça; Secretaria Nacional de Políticas sobre Drogas. Prevenção ao uso indevido de drogas: capacitação para conselheiros e lideranças comunitárias. $3^{\mathrm{a}}$ ed. Brasília: SENAD; 2010

- Cook L. J., (2007), "Striving to help college students with mental health issues", Journal of psychosocial nursing mental health services. Apr. 45(4), Pp. 40-44.

-Earsl F., (2001), "Community factors supporting child mental health", child \& adolescent psychiatric clinics of North America, Oct. 10(4), Pp. 693-709.

- Fundo das Nações Unidas para a Infância (UNICEF). O direito de ser adolescente: oportunidade para reduzir vulnerabilidades e superar desigualdades. Brasília: UNICEF; 2011

-Garfinkle B. (2000), "Suicidal behavior in children \& adolescents". Journal of abnormal child psychology. Jan. 10(2), Pp. 227-84.

-Hall C.S., (2002), "Theories of personality", $4^{\text {th }}$ edition, John Wiley \& Sons, New York. Pp. 201-2.

-Morrison, M. (1998), "Foundations of mental health nursing”, $1^{\text {st }}$ edition, Mosby yearbook, Inc. St. Louis, Missoury. Pp. 212.

-Lachowski S. et. al., (2007), "Mental well-being of children $\&$ quality of family environment", Environmental medicine, Dec. 14(1), Pp. 115-21. 
- Mynayo MCS, Sanches O. Quantitative and qualitative methods: opposition or complementarity? Cad Saúde Pública. 1993;9(3):239-62

- Oliveira AGB, Alessi NP. O trabalho de enfermagem em saúde mental: contradições e potencialidades atuais. Rev Latino Am Enferm. 2003;11(3):333-40.

- Organização Mundial de Saúde (OMS). Relatório Mundial da Saúde. Saúde mental: nova concepção, nova esperança [Internet]. Brasília: Direção Geral de Saúde; 2002 [citado 2012 maio 20]. Disponível em: http://www.who.int/whr/2001/en/whr01_djmessage_ po.pdf
-Singh M., (2004), "Role of micronutrients for physical growth \& mental development", Indian journal of pediatrics, Jan, 71(1), Pp. 59-62.

- United Nations; Department of Economic and Social Affairs, Population Division.World Population Prospects: the 2008 revision [Internet]. New York; 2009[cited 2012 May 20]. Available from: http://www.un.org/esa/population/publicatWions/wp p2008/wpp2008 highlights.pdf

- WHO report, 2018; https://www.who.int/newsroom/fact-sheets/detail/adolescent-mental-health 